\title{
Phylogeny and Biogeography of South American Marsh Pitcher Plant Genus Heliamphora (Sarraceniaceae) Endemic to the Guiana Highlands
}

\author{
Sukuan Liu and Stacey D. Smith
}

Author for correspondence: Sukuan Liu, sukuan.liu@ colorado.edu

Department of Ecology and Evolutionary Biology, University of Colorado Boulder, 1900 Pleasant Street, Boulder, Colorado 80309, U.S.A.

\begin{abstract}
Heliamphora is a genus of carnivorous pitcher plants endemic to the Guiana Highlands with fragmented distributions. We presented a well resolved, time-calibrated, and nearly comprehensive Heliamphora phylogeny estimated using Bayesian inference and maximum likelihood based on nuclear genes (26S, ITS, and PHYC) and secondary calibration. We used stochastic mapping to infer ancestral states of morphological characters and ecological traits. Our ancestral state estimations revealed that the pitcher drainage structures characteristic of the genus transformed from a hole to a slit in single clade, while other features (scape pubescence and hammock-like growth) have been gained and lost multiple times. Habitat was similarly labile in Heliamphora, with multiple transitions from the ancestral highland habitats into the lowlands. Using Mantel test, we found closely related species tend to be geographically closely distributed. Placing our phylogeny in a historical context, major clades likely emerged through both vicariance and dispersal during Miocene with more recent diversification driven by vertical displacement during the Pleistocene glacial-interglacial thermal oscillations. Despite the dynamic climatic history experienced by Heliamphora, the temperature changes brought by global warming pose a significant threat, particularly for those species at the highest elevations.
\end{abstract}

Keywords: Sarraceniaceae, Heliamphora, Carnivorous Plants, Pantepui, Guiana Highlands, Neotropics

\section{Introduction}

The marsh pitcher plant Heliamphora (Sarraceniaceae) is a carnivorous plant genus endemic to the Guiana Highland across Venezuela, Guyana, and Brazil (Berry, Huber et al. 1995, Rull 2009, Rull, Huber et al. 2019). They are only found in the Pantepui region where the tepuis, or 
sandstone table-top mountains, rise above the surrounding lowlands (Maguire 1978, McPherson, Wistuba et al. 2011). The Pantepui region, compared to the lowland savannah, has distinct climatic, geomorphological, hydrological, and ecological features, hosting a diverse assembly of endemics with specialized adaptations (Huber 1995, McPherson 2008, Rull, Huber et al. 2019). The environments are characterized by cold temperatures, exposed surfaces, infertile substrates, and heavy precipitation (McPherson 2008, Zinck and Huber 2011).

Such harsh conditions favor diverse endemic carnivorous plant genera (e.g. Heliamphora, Utricularia, Genlisea, Drosera and semi-carnivorous Brocchinia), which thrive in the infertile areas where few non-carnivorous species are found (Brewer and Schlauer 2018, Fleischmann, Schlauer et al. 2018). Among the Pantepui endemics, the carnivorous syndrome is manifested through both morphological and molecular adaptations (Juniper, Robins et al. 1989, Matušíková, Pavlovic et al. 2018), enabling them to attract, kill and digest insect prey for additional nutrients (Brewer and Schlauer 2018). The leaves of Heliamphora are not only photosynthetic but also highly modified pitchers with structures specialized in carnivorous functions (McPherson, Wistuba et al. 2011). Heliamphora produces nectar as attractant in the nectar spoon above the pitcher opening (Płachno and Muravnik 2018), enticing prey to fall into the pitcher filled with digestive liquid. The prey then drown and are digested, allowing the plant to absorb the nutrients rich in nitrogen and phosphorous (Maguire 1978, Juniper, Robins et al. 1989). Unlike other pitcher plants (Sarracenia, Darlingtonia, Nepenthes and Cephalotus) that have lids or hoods covering the pitcher, Heliamphora do not have similar structures to prevent rainwater from entering the adult pitchers. Instead, the adult pitchers of Heliamphora are adapted to the high rainfall in the Pantepui by allowing excess rainwater to flow through a drainage hole or slit below the pitcher opening (McPherson, Wistuba et al. 2011). Additionally, the retentive hairs above the digestive fluid and around drainage structures act as filters that prevent captured prey from escaping from the pitchers (Jaffe, Michelangeli et al. 1992).

Heliamphora populations are generally confined to the montane or tepui summits at elevations above 1500m (McPherson, Wistuba et al. 2011). While some species are distributed across a group of near-by tepuis (massifs or tepui chains), more than half of the genus only occurs in single tepuis, valleys, canyons, or upland swamps (McPherson, Wistuba et al. 2011). Poor seed dispersibility and presence of lowland savannah acting as dispersal barrier may have contributed to this high degree of endemism. It had been suggested that Heliamphora might have diversified through allopatric speciation as the once continuous highland habitat gradually fragmented over time through erosion (Maguire 1978, Huber 1987, McPherson, Wistuba et al. 2011, Huber 2018).

In this study, we estimated the time-calibrated phylogeny of Heliamphora in order to resolve relationships within the genus and trace its diversification over space and time. We tested the relationship between geographic and genetic distance, with the expectation that low dispersal ability would result in close relatives living in close proximity. We also estimated the history of changes in habitats using ancestral state reconstruction to test for directionality in transitions (i.e. highland vs. lowland). Finally, we reconstructed key morphological characters to identify traits diagnostic of clades. In interpreting these results, we considered possible modes of speciation and discussed the possible impacts of global climate change on the future of Heliamphora. 


\section{Materials and methods}

\subsection{Taxon Sampling}

Recent treatments of Heliamphora recognize 23 species, most of which were described since 2000 (McPherson, Wistuba et al. 2011). We sampled 22 described Heliamphora species (all except $H$. macdonaldae) plus 2 undescribed taxa from collectors or commercial sources for the phylogenetic analysis (Appx. A Sample Accession Numbers and Sources). We confirmed species determinations by comparing the morphological traits of these living collections to the original descriptions (Bentham 1840, Nerz and Wistuba 2000, Wistuba, Harbarth et al. 2001, Wistuba, Carow et al. 2002, Carow, Wistuba et al. 2005, Wistuba, Carow et al. 2005, Fleischmann, Wistuba et al. 2009). We also sampled five taxa (Sarracenia leucophylla, S. pittacina, Darlingtonia californica, Roridula gorgonias and Actinidia arguta) to serve as outgroups (Appx. A Sample Accession Numbers and Sources). Previous work had supported the monophyly of Sarraceniaceae (comprising the three genera, Sarracenia, Heliamphora and the monotypic Darlingtonia) and shown that Roridulaceae+Actinidiaceae were sister to the family (Ellison, Butler et al. 2012, Magallón, Gomez-Acevedo et al. 2015).

\subsection{DNA Extraction, Amplification and Sequencing}

All Heliamphora, Sarracenia psittacina, and Darlingtonia californica were grown under controlled environmental conditions (photoperiod $15 \mathrm{hr}$ per day; temperature range $12-24{ }^{\circ} \mathrm{C}$; relative humidity $>80 \%$ ) inside of growth chambers under artificial lights with temperature/humidity regulating units in the University of Colorado Boulder before DNA extraction. DNA was extracted from 0.5-1.0 grams of fresh, young, and unopened pitchers using the CTAB protocol (Doyle and Doyle 1987).

We amplified and sequenced three nuclear genes (ITS, 26S, PHYC) using polymerase chain reaction (PCR) amplification and Sanger Sequencing. The markers had shown potential in resolving interspecies relationships in Sarraceniaceae from a previous study (Ellison, Butler et al. 2012). The ITS region was amplified using the primers ITS4 (White, Bruns et al. 1990) and ITS5 (Ristaino, Madritch et al. 1997) or ITSLEU (Baum, Small et al. 1998). The 26S region was amplified using overlapping primer sets N-nc26S1/1229rev, N-nc26S4/1499rev, Nnc26S4/2134rev, nc26S9/3058rev, and nc26S9/3331rev (Kuzoff, Sweere et al. 1998). PHYC was amplified using primers cdo (Mathews and Donoghue 1999) and int1F (Wurdack and Davis 2009). The PCR conditions and recipes are provided in Appendix B (PCR Mix Recipes and Conditions). Sequences for three of the outgroups (S. leucophylla, R. gorgonias, and A. arguta) were available from previous studies (Ellison, Butler et al. 2012, Lo $\square$ fstrand and Scho $\square$ nenberger 2015) and were downloaded from GenBank (Appx. A).

\subsection{Phylogenetic Analysis}

Nucleotide sequences were de novo assembled from chromatogram files in Geneious 11.1.5 (https://www.geneious.com). All sequences were first aligned under default settings (Geneious global alignment with free end gaps and 93\% similarity cost matrix). Uncertain positions, where peaks corresponding to different bases were similar in height, were scored as ambiguous (e.g., W 
for $\mathrm{A}$ or $\mathrm{T})$. The alignment was trimmed at the two ends so that all sequences were mostly overlapping and similar in length. Bayesian phylogenetic analysis was carried out in BEAST 2.5.2 (Bouckaert, Heled et al. 2014). Nucleotide substitution models were chosen for each marker by running alignments in jModeltest 2.1.10 with the Bayesian information criterion (Guindon and Gascuel 2003, Darriba, Taboada et al. 2012). GTR + G + I, TN93, and HKY models were selected for 26S, ITS and PHYC, respectively. We used a birth-death process for diversification priors. We constrained $R$. gorgonias and $A$. arguta to form a clade given the lack of complete genetic data in this study and the well-supported relationships from previous studies (Ellison, Butler et al. 2012, Lo $\square$ fstrand and Scho $\square$ nenberger 2015). A chain length of 30 million generations sampling every 1000 trees was used to estimate the model parameters. We verified that all parameters had ESS values above 200 using Tracer 1.7.1 (Rambaut, Drummond et al. 2018). TreeAnnotator 2.4 .7 was used to generate a maximum clade credibility (MCC) tree with posterior probabilities (Bouckaert, Heled et al. 2014). The MCC tree was first visualized in FigTree 1.4.4 (http://tree.bio.ed.ac.uk/software/figtree/), then further edited in Affinity Designer 1.7.1. We also estimated individual gene trees in RAxML 8.2.10 (Stamatakis 2014) using the GTRGAMMA model with 1000 bootstraps using CIPRES Portal (Miller, Pfeiffer et al. 2010).

\subsection{Divergence Time Calibration}

Two secondary calibration points were used to estimate node ages in Sarraceniaceae, further supported by several fossils dated prior to those estimations. A fossil named Archaeamphora longicervia Hongqi Li was first assigned to Sarraceniaceae due to its structural similarity to Heliamphora and Sarracenia purpurea (Li 2005). However, its early Cretaceous age ( 125Ma) made it unlikely to be an early representative of Sarraceniaceae since several studies with robust fossil calibrations found the family to be younger than $90 \mathrm{Ma}$ (Magallón, Gómez-Acevedo et al. 2015, Tank, Eastman et al. 2015, Wong, Dilcher et al. 2015, Rosea, Kleistb et al. 2018). Several fossils had been described in Actinidiaceae, with Parasaurauia allonensis (Keller, Herendeen et al. 1996), Paradinandra suecica (Schönenberger and Friis 2001), and Glandulocalyx upatoiensis (Schönenberger, Balthazar et al. 2012) dating back in the late Santonian ( 84 Ma). In Roridulaceae, well preserved Roridula carnivorous leave fossils were discovered in Eocene Baltic amber dating to less than $47 \mathrm{Ma}$, indicating that Roridulaceae emerged before $47 \mathrm{Ma}$ but probably after 84Ma (Sadowski, Seyfullah et al. 2015). The robust, fossil calibrated angiosperm phylogeny from Magallón et al. (2015) estimated the mean ages of Sarraceniaceae+Roridulaceae/Actinidiaceae and Roridulaceae+Actinidiaceae to be 88.09 and 83.58 Ma, respectively (Magallón, Gómez-Acevedo et al. 2015). Given the concordance with the fossil dates, we chose to use these estimates from the angiosperm-wide analysis (Magallón, Gómez-Acevedo et al. 2015) as secondary calibrations. We entered 88.1 (95\%HPD:85.2-91.0) and 83.6 (95\%HPD:82.8-86.8) Ma as priors for those nodes indicated above.

\subsection{Mantel Test for Phylogenetic Signal in Geographic Distribution}

Methods centered on biogeographic models, such as dispersal-extinction-cladogenesis (DEC) (Ree, Moore et al. 2005, Ree and Smith 2008) and its extensions (Matzke 2013), have often been used to infer range shifts (Matzke 2014, Klaus, Morley et al. 2016, Fuchs, Pons et al. 2017) and and could be applied to Heliamphora. However, conceptual and statistical issues were recently identified that make likelihood comparisons between DEC and DEC $+\mathrm{j}$ models invalid (Ree and 
Sanmartín 2018). Although alternatives, like ClaSSE (Goldberg and Igic 2012) corrected the issue by modeling cladogenesis as time-dependent probabilities, they are too parameter rich to be applied to Heliamphora, given its small size and complex local distribution patterns. Instead, we implemented a simpler Mantel test in R 3.6.1 to test for correlation between genetic and geographical distance between each species (Diniz-Filho, Soares et al. 2013). We predicted that the potential limited dispersal ability of Heliamphora (Cross, Davis et al. 2018) would lead to a strong phylogenetic signal in geography, with close relatives tending to occur in close proximity. We used the estimated phylogeny to produce the genetic distance matrix. We then used centroid coordinates (Appx. C Species Distributions) from each species' known distribution in McPherson et al. (2011) to produce the geographical distance matrix.

\subsection{Ancestral State Estimation}

A range of morphological features, such as aspects of pitcher size, form and pubescence, are diagnostic for Heliamphora species (McPherson, Wistuba et al. 2011). We estimated the evolutionary histories of three such morphological characters: drainage hole, scape pubescence, and growth form. As some of these traits are absent in the outgroups, we first pruned the phylogeny to include only Heliamphora. Trait evolution was estimated using stochastic mapping with the function "make.simmap" in phytools 0.6-99 (Revell 2012). All characters except for scape pubescence were scored as binary based on species descriptions (Bentham 1840, Steyermark 1951, McPherson, Wistuba et al. 2011). Scape pubescence was scored as "glabrous", "pubescent" and "glabrous+pubescent" as some species are found to have both pubescent and glabrous scapes. After stochastic mapping, we combined later two states as "pubescent" as we disregarded transitions between "pubescent" and "glabrous+pubescent". For every character, we compared for two transition rate models: the equal rates (ER) model and the all rates different (ARD) model (Pagel 1994, Schluter, Price et al. 1997). The best fit model for each character was selected based on the lowest AIC scores and used for stochastic mapping. We also examined habitat shifts in Heliamphora using the same approach. We scored habitat types as either Upper or Lower Pantepui (highland vs. lowland habitats) based on a taxon's lowest distribution. We used $1500 \mathrm{~m}$ as our threshold elevation for habitat types because drastic shifts in local climate, geomorphology, and community composition were observed at this elevation (Huber 1987, Rull, Huber et al. 2019).

\section{Results}

\subsection{Phylogenetic Analysis \& Divergence Time Estimation}

Our analysis supported the sister clade relationship between Sarracenia and Heliamphora, in accordance with previous studies (Neyland and Merchant 2006, Ellison, Butler et al. 2012, Stephens, Rogers et al. 2015). Within Heliamphora, we recovered well supported subclades found in the western (W) and the eastern (E) Pantepui region. For the purpose of discussion, we divided the species-rich eastern clades into four (E1, E2a, E2b, E3) (Fig. 1). In Heliamphora, the monophyly of all sub-clades and even most of the interspecies relationships were well supported (posterior probability $>0.99$ ) by our combined nuclear data set. Relationships within Heliamphora showed strong geographic structure. For example, the $\mathrm{W}$ clade was restricted to the 
western Pantepui and the E3 clade to the Eastern Tepui Chain (Fig. 1). Both 26S (3251bp) and ITS regions (676bp) supported the monophyly (bootstrap scores BS > 80) of the W, E1, E2 and E3 clades (Appx. D Individual Gene Trees Estimated Using Maximum Likelihood) . PHYC (787bp) provided good support $(\mathrm{BS}>85)$ for the monophyly of the sub-clades E2a and E2b (Appx. D). Using the two previously described node calibrations, we estimated that Sarracenia and Heliamphora split ca. 14 mya, and that the various subclades diverged between 6 and 2 mya (Fig. 1).

\subsection{Mantel Test and Biogeography}

Our null hypothesis (no correlation between genetic and geographic distance) was rejected by the Mantel test $(\mathrm{p}<0.001, \mathrm{r}=0.43)$, suggesting that genetic distances are correlated with geographic distances. This result indicates that close relatives tend to be distributed closely and distantly related species farther apart. The geographic structuring is apparent from the the phylogeny, where species in each subclade were clustered within the Pantepui (Fig. 1). One exception was the E2b clade, which is widespread in the eastern region. Also, the western clade (W) is monophyletic but nested within the genus, making eastern clade (E1, E2, and E3) paraphyletic.

\subsection{Ancestral State Estimation}

Based on the AIC scores, the ER model was selected to estimate the ancestral states of the drainage structure and scape pubescence (Fig. 2). The ARD model was selected for the evolution of growth form and habitats. For the drainage structure, we estimated a single transition from drainage hole to slit [median: 1 with $95 \%$ credibility interval (CI): 0-2 and likely no reverse transitions] (Fig. 2). The median transition numbers from glabrous to pubescent scape and vice versa were estimated to be 2 (CI: 0-6) and 2 (CI: 1-4), respectively (original 3 state transition ASR see Appx. E). The adaptation and loss to hammock-like clumpy growth form was inferred to be frequently gained and lost with median numbers of transitions estimated to be 36 (CI: 1480) and 37.5 (CI: 14-80), respectively (Appx. E Ancestral State Reconstruction for Growth Forms and Habitats). Similarly, the transitions between highland and lowland habitat was inferred to be frequent from both directions [34 (CI: 13-74) and 34 (CI: 12-77)] (Appx. E). We suspect that these extremely high numbers of inferred transitions reflects high rates estimated along short branches in the tree (see Discussion 4.1.2).

\section{Discussion}

The previous family-level analysis (Ellison, Butler et al. 2012) recovered a monophyletic Heliamphora (with six taxa sampled), but with low levels of support for relationships within the genus. With newly obtained sequence data for all Heliamphora but H. macdonaldae, we were able to resolve relationships among most of the taxa with strong support. Using updated secondary calibration points, we recovered age estimates that were generally older than those in previous studies (Ellison, Butler et al. 2012, Rose, Kleist et al. 2018) but in accordance with known fossil records for Ericales (Sadowski, Seyfullah et al. 2015). In the context of this new phylogeny, we discuss patterns of trait evolution and possible biogeographical histories that 
might have shaped present-day Heliamphora distributions along with the implications of global warming for the future of this clade.

\subsection{Evolution of Morphological and Ecological Traits}

\subsubsection{Drainage Structures \& Scape Pubescence}

Drainage structures, in the form of holes or slits in the pitchers, allow Heliamphora to regulate fluid levels by draining excess rainwater out while retaining captured prey (McPherson, Wistuba et al. 2011). No homologous drainage structures are present in Sarracenia or Darlingtonia, suggesting that these structures evolved in ancestral Heliamphora populations, presumably as an adaptation to the perhumid climate in the Pantepui region. The drainage slit (Fig. 2) is found exclusively in the E1 clade where a narrow $\mathrm{V}$-shaped slit extends from pitcher opening to the upper half of the ventral suture. In the rest of Heliamphora, the drainage hole is present and generally positioned at the lower half of the ventral suture. Our analysis revealed that the hole is the ancestral state in Heliamphora and was further modified into drainage slit (Fig. 2).

Scape pubescence was another character of taxonomic importance, although our analysis indicated it has a complex history. We inferred that a pubescent scape is ancestral in Heliamphora but was further lost in the ancestral population leading to E2 clade (Fig. 2). Moreover, our analysis suggested that pubescent scape might have been independently lost in $H$. minor, $H$. nutans, and $H$. ionasi, showing this trait could be frequently lost during diversification.

\subsubsection{Highland to Lowland Transitions}

Most of Heliamphora species occur exclusively in the upper Pantepui region at elevations higher than $1500 \mathrm{~m}$ (Fig. 2). However, a few species could be found in the lower elevations below 1500m (Appx. C). H. glabra and H. heterodoxa are distributed from upper Pantepui into the lower elevations at around $1200 \mathrm{~m}$ while $H$. ciliata is the only species that occur exclusively in the lowland at $900 \mathrm{~m}$. Our analysis suggested that the most likely ancestral state across the clade is highland (Appx. E), but we also estimated frequent transitions between upper and lower Pantepui habitats (see Results 3.3). Given that only three taxa occur in lower elevations, we consider the high number of inferred transitions to be a spurious result relating to the short branch lengths separating sister taxa occurring in different habitats (e.g. H. ciliata in Lower Pantepui vs. H. chimantensis in Upper Pantepui). The presence of such contrasts separated by short time periods results in high estimated transition rates in Markov models of trait evolution (Pagel, Meade et al. 2004).

\subsubsection{Hammock-like Clump Growth Habit}

Diverse growth habits are found in Heliamphora, possibly as adaptations to the local environments (McPherson, Wistuba et al. 2011). Some species occurring in exposed summit environment tend to exist in extensive clonal populations, forming hammock-like clumps up to several meters in diameter (Wistuba, Carow et al. 2002, Wistuba, Carow et al. 2005) while other species growing in densely vegetated montane habitat tend to grow singly or even stem forming (McPherson, Wistuba et al. 2011). Our ancestral state reconstruction suggested that growth form 
was not highly conserved, with multiple shifts along the phylogeny (Appx. E). Nevertheless, ancestral states were uncertain throughout, leaving it unclear when these transitions have occurred. Future studies would be valuable to test the ecological drivers of this growth habit variation.

\subsection{Evolutionary and Biogeographical Histories}

After the ancestral lineage split into two major lineages giving rise to W/E1 and E2/E3 in the early Miocene, Heliamphora underwent three waves of diversification (Fig. 3). The first event occurred during Late Miocene when E2 and E3 diversified shortly followed by the splitting of W and E1. During the transition between Miocene and Pliocene, the second wave took place when E2 further split into E2a and E2b, followed by further diversification of $\mathrm{W}$ and E1 clades. The split of $H$. tatei (together with its potential sister $H$. macdonaldae, not sampled here) from the rest of $\mathrm{W}$ clade might have taken place due to lack of connectivity between Duida-Marahuaca Massif and Neblina-Aracamuni Massif. Similarly, the divergence of $H$. minor from the rest of E1 clade could have resulted from allopatric speciation when Auyán Tepui and Chimantá Massif lost their connectivity (Rull and Nogué 2007). The last wave of diversification occurred from the late Pliocene into Quaternary when rapid speciation took place within all Heliamphora clades.

The high degree of endemism in Heliamphora clades suggests that vicariance or short distance dispersal could have played an important role in shaping the present-day diversity. As supported by our Mantel test, closely related species showed strong geographic clustering. The distributional pattern was consistent with the hypothesis proposed by Maguire (1970) that many Pantepui endemics, like Heliamphora, could have once occurred on a more continuous highland habitat but later diversified as the highland gradually became eroded, fragmented and eventually separated (Maguire 1970). Still, the nested position of the west (W) clade within the eastern clades points to a more complex biogeography history, potentially involving rare long distance dispersal from the eastern region.

While biogeographic events such as vicariance and dispersal may account for the origins of major clades, more recent climatic oscillations could have contributed to recent diversification events within the genus. Available paleoclimatic data (Zachos, Dickens et al. 2008, Hansen, Sato et al. 2013) suggest that the Pantepui region might have experienced a warmer climate during the early Miocene but entered rapid cooling phase since mid-Pliocene (Fig. 3). By the Pleistocene, thermal oscillations initiated and average temperature shifts of more than $8^{\circ} \mathrm{C}$ frequently occurred during the transition between glacial and interglacial periods (Rull and VegasVilarrúbia 2019). Although the tepui summits were never glaciated during glacial periods (Rull, Montoya et al. 2019), the drastic temperature shifts would have profound effect on the distributions of Heliamphora in the Pantepui (Steyermark and Dunsterville 1980). During the glacial periods, the highland habitats could have shifted downward (Rull and Vegas-Vilarrúbia 2019), allowing Heliamphora populations to descend, colonize surrounding lower elevations and open new migrational routes between tepui summits (Steyermark and Dunsterville 1980, Rull 2005, Rull and Nogué 2007). In the warmer interglacial periods, Heliamphora populations may have migrated to higher elevations where suitable habitats had advanced back up (Rull 2005, Rull and Nogué 2007). Pollen analysis of peat outcrops deposited on tepui summits during the warmer, more stable Holocene revealed Heliamphora and other Pantepui endemic communities 
had shifted distributions for at least a few hundred meters in response to temperature shifts (Rull 2004, Rull, Montoya et al. 2011). This indicated that more intense vertical displacements would have potentially occurred during the stronger thermal oscillations in Pleistocene, allowing Heliamphora to descend downward to up to $1,100 \mathrm{~m}$ into the lowlands (Farrera, Harrison et al. 1999, Rull and Nogué 2007, Rull and Vegas-Vilarrúbia 2019).

\subsection{Evolutionary Future in a Warming Climate}

Thus far, Heliamphora has largely remained unthreatened thanks to the remoteness and inaccessibility of their native habitats with few historical anthropogenic disturbances (McPherson, Wistuba et al. 2011, Safont, Rull et al. 2016, Bevilacqua, Señaris et al. 2019). However, ongoing effect of global warming poses a severe threat to Heliamphora (Nogué, Rull et al. 2009, Rull, Nogué et al. 2019). The global temperature is projected to increase $2-4{ }^{\circ} \mathrm{C}$ by the end of the century (JT, Y et al. 2001), rendering it hotter than any interglacial periods ever experienced during the Pleistocene (Fig. 3). Such projected temperature increase would cause Heliamphora suitable habitats to shift upward 300-600m in elevation (Rull, Nogué et al. 2019). Heliamphora species restricted to tepui summits with smaller areas and lower elevations (e.g. $H$. sarracenioides, $H$. purpurascens and $H$. spec. nov. 'Angasima') would lose suitable habitats with no higher elevation to migrate to, and eventually go extinct (Appx. C). Other Heliamphora species, if they survive the warming by rapidly dispersing and colonizing upward, would still suffer severe habitat loss by $25-98 \%$ due to reduction of available surface area towards higher elevations (Nogué, Rull et al. 2009).

Funding: This work was supported by the University of Colorado Boulder [EBIO Graduate Students Research Grants, 2017, 2018, 2019; Beverly Sears Graduate Student Research Grant, 2018]. 


\section{Bibliography}

Baum, D. A., R. L. Small and J. F. Wendel (1998). "Biogeography and Floral Evolution of Baobabs (Adansonia , Bombacaceae) as Inferred from Multiple Data Sets." Systematic Biology 47(2): 181-207. Bentham, G. (1840). "XXV. On the Heliamphora nutans, a new pitcher-plant from British Guiana." The Transactions of the Linnean Society of London 18(3): 429-433.

Berry, P. E., O. Huber and B. K. Holst (1995). Floristic analysis and phytogeography. Flora of the Venezuelan Guayana. P. E. Berry, B. K. Holst and K. Yatskievych. St. Louis, Missouri Botanical Garden Press. 1: 161-191.

Bevilacqua, M., C. Señaris and O. Huber (2019). Conservation of Pantepui: between complex emergency and climate change. Biodiversity of Pantepui. V. Rull, T. Vegas-Vilarrúbia, O. Huber and C. Señaris, Academic Press: 389-402.

Bouckaert, R., J. Heled, D. Kühnert, T. Vaughan, C.-H. Wu, D. Xie, M. A. Suchard, A. Rambaut and A. J. Drummond (2014). "BEAST 2: A Software Platform for Bayesian Evolutionary Analysis." PLOS Computational Biology 10(4).

Brewer, S. J. and J. Schlauer (2018). Biogeography and habitats of carnivorous plants. Carnivorous Plants Physiology, ecology, and evolution. A. Ellison and L. Adamec, Oxford University Press: 7-21.

Carow, T., A. Wistuba and P. Harbarth (2005). "Heliamphora sarracenioides, a New Species of Heliamphora (Sarraceniaceae) from Venezuela." Carnivorous Plant Newsletter 34(1): 4 - 6.

Cross, A. T., A. R. Davis, A. Fleischmann, J. D. Horner, A. Jürgens, D. J. Merritt, G. L. Murza and S. R. Turner (2018). Reproductive biology and pollinator-prey conflicts. Carnivorous Plants Physiology, ecology, and evolution. A. Ellison and L. Adamec, Oxford University Press: 294-313.

Darriba, D., G. L. Taboada, R. Doallo and D. Posada (2012). "jModelTest 2: more models, new heuristics and parallel computing." Nature Methods 9(8): 772.

Diniz-Filho, J. A. F., T. N. Soares, J. S. Lima, R. Dobrovolski, V. L. Landeiro, M. P. d. C. Telles, T. F. Rangel and L. M. Bini (2013). "Mantel test in population genetics." Genetics and Molecular Biology 36(4): 475-485.

Doyle, J. J. and J. L. Doyle (1987). "A rapid DNA isolation procedure for small quantities of fresh leaf tissue." Phytochemical Bulletin 19: 11-15.

Ellison, A. M., E. D. Butler, E. J. Hicks, R. F. C. Naczi, P. J. Calie, C. D. Bell and C. C. Davis (2012). "Phylogeny and Biogeography of the Carnivorous PlantFamily Sarraceniaceae." PLOS ONE 7(6).

Farrera, I., S. P. Harrison, I. C. Prentice, G. Ramstein, J. Guiot, P. J. Bartlein, R. Bonnefille, M. Bush, W. Cramer, U. v. Grafenstein, K. Holmgren, H. Hooghiemstra, G. Hope, D. Jolly, S.-E. Lauritzen, Y. Ono, S. Pinot, M. Stute and G. Yu (1999). "Tropical climates at the Last Glacial Maximum: a new synthesis of terrestrial palaeoclimate data. I. Vegetation, lake-levels and geochemistry." Climate Dynamics 15(11): 823-856.

Fleischmann, A., J. Schlauer, S. A. Smith and T. J. Givnish (2018). Evolution of carnivory in angiosperms. Carnivorous Plants Physiology, ecology, and evolution. A. Ellison and L. Adamec, Oxford University Press: 22-42.

Fleischmann, A., A. Wistuba and J. Nerz (2009). "Three new species of Heliamphora (Sarraceniaceae) from the Guayana Highlands of Venezuela." Willdenowia 39(2): 273-283.

Goldberg, E. E. and B. Igic (2012). "Tempo and mode in plant breeding system evolution." Evolution 66(12): 3701-3709.

Guindon, S. and O. Gascuel (2003). "A simple, fast and accurate method to estimate large phylogenies by maximum-likelihood"." Systematic Biology 52: 696-704.

Hansen, J., M. Sato, G. Russell and P. Kharecha (2013). "Climate Sensitivity, Sea Level and Atmospheric Carbondioxide." Philosophocal Transactions of The Royal Society A.

Huber, O. (1987). "Vegetacion y flora de Pantepui, Region Guayana." Acta Botanica Brasilica 1(2). Huber, O. (1995). Vegetation. Flora of the Venezuelan Guayana. P. E. Berry, B. K. Holst and K. Yatskievych. St. Louis, Missouri Botanical Garden Press. 1: 97-160. 
Huber, O. (2018). The Tepuis of the Guiana Highlands. Mountains, Climate and Biodiversity. C. Hoorn, A. Perrigo and A. Antonelli, John Wiley \& Sons, Incorporated: 669-692.

Jaffe, K., F. Michelangeli, J. M. Gonzalez, B. Miras and M. C. Ruiz (1992). "Carnivory in pitcher plants of the genus Heliamphora (Sarraceniaceae)." The New Phytologist 122(4): 733-744.

JT, H., D. Y, G. DG, N. M, v. d. L. PJ, D. X, M. K and J. CA (2001). Climate change 2001, the scientific basis. Cambridge, Cambridge University Press.

Juniper, B. E., R. J. Robins and D. M. Joel (1989). The Carnivorous Plants. London, Academic Press Ltd. Keller, J. A., P. S. Herendeen and P. R. Crane (1996). "Fossil flowers and fruits of the Actinidiaceae from the Campanian (Late Cretaceous) of Georgia." American Journal of Botany 83(4): 528-541.

Kuzoff, R. K., J. A. Sweere, D. E. Soltis, P. S. Soltis and E. A. Zimmer† (1998). "The Phylogenetic Potential of Entire 26S rDNA Sequences in Plants." Molecular Biology and Evolution 15(3): 251-263. Li, H. (2005). "Early Cretaceous sarraceniacean-like pitcherplants from China." Acta Botanica Gallica 152(2): 227-234.

Lo $\square$ fstrand, S. D. and J. r. Scho $\square$ nenberger (2015). "Molecular phylogenetics and floral evolution in the sarracenioid clade (Actinidiaceae, Roridulaceae and Sarraceniaceae) of Ericales." Taxon 64(6): 12091224.

Magallón, S., S. Gomez-Acevedo, L. L. Sanchez-Reyes and T. Hernandez-Hernandez (2015). "A metacalibrated time-tree documents the early rise of floweringplant phylogenetic diversity." $\mathrm{New}$ Phytologist 207: 437-453.

Magallón, S., S. Gómez-Acevedo, L. L. Sánchez-Reyes and T. Hernández-Hernández (2015). "A metacalibrated time-tree documents the early rise of floweringplant phylogenetic diversity." $\mathrm{New}$ Phytologist 207: 437-453.

Maguire, B. (1970). "On the Flora of the Guayana Highland." Biotropica 2(2): 85-100. Maguire, B. (1978). "Botany of the Guayana Highland: Sarraceniaceae." Memoirs of The New York Botanical Garden 29: 26-62.

Mathews, S. and M. J. Donoghue (1999). "The Root of Angiosperm Phylogeny Inferred from Duplicate Phytochrome Genes." Science 286(5441): 947-950.

Matušíková, I., A. Pavlovic and T. Renner (2018). Biochemistry of prey digestion and nutrient absorption. Carnivorous Plants Physiology, ecology, and evolution. A. Ellison and L. Adamec, Oxford University Press: 207-220.

Matzke, N. J. (2013). BioGeoBEARS: BioGeography with Bayesian (and Likelihood) Evolutionary Analysis in R Scripts. Berkeley, CA, University of California, Berkeley.

McPherson, S. (2008). Lost Worlds of the Guiana Highlands. England, Redfern Natural History

Productions.

McPherson, S., A. Wistuba, A. Fleischmann and J. Nerz (2011). Sarraceniaceae of South America. Poole, United Kingdom, Redfern Natural History Productions.

Miller, M. A., W. Pfeiffer and T. Schwartz (2010). Creating the CIPRES Science Gateway for Inference of Large Phylogenetic Trees. S. D. S. Center. New Orleans: 1-8.

Nerz, J. and A. Wistuba (2000). "Heliamphora hispida (Sarraceniaceae), a new species from Cerro Neblina, Brazil-Venezuela." Carnivorous Plant Newsletter 29: 37-41.

Neyland, R. and M. Merchant (2006). "Systematic relationships of Sarraceniaceae inferred from nuclear ribosomal DNA sequences." Madroño 53(3): 223-232.

Nogué, S., V. Rull and T. Vegas-Vilarrúbia (2009). "Modeling biodiversity loss by global warmingon

Pantepui, northern South America: projectedupward migration and potential habitat loss." Climatic Change 94: 77-85.

Pagel, M. (1994). "Detecting correlated evolution on phylogenies: a general method for the comparative analysis of discrete characters." Proceedings of the Royal Society B 255(1342): 37-45.

Pagel, M., A. Meade and D. Barker (2004). "Bayesian Estimation of Ancestral Character States on Phylogenies." Systematic Biology 53(5): 673-684.

Płachno, B. J. and L. E. Muravnik (2018). Functional anatomy of carnivorous traps. Carnivorous Plants Physiology, ecology, and evolution. A. Ellison and L. Adamec, Oxford University Press: 167-179. 
Rambaut, A., A. J. Drummond, D. Xie, G. Baele and M. A. Suchard (2018). "Posterior summarisation in Bayesian phylogenetics using Tracer 1.7." Systematic Biology 67(5): 901-904.

Ree, R. H., B. R. Moore, C. O. Webb and M. J. Donoghue (2005). "A likelihood framework for inferring the evolution of geographic range on phylogenetic trees." Evolution 59(11): 299-2311.

Ree, R. H. and I. Sanmartín (2018). "Conceptual and statistical problems with the DEC+ J model of founder-event speciation and its comparison with DEC via model selection." Journal of Biogeography 45 : 741-749.

Ree, R. H. and S. A. Smith (2008). "Maximum Likelihood Inference of Geographic Range Evolution by Dispersal, Local Extinction, and Cladogenesis." Systematic Biology 57(1): 4-14.

Revell, L. J. (2012). "Phytools: an R package for phylogenetic comparativebiology (and other things)." Methods in Ecology and Evolution 3.

Ristaino, J. B., M. Madritch, C. L. Trout and G. Parra (1997). "PCR Amplification of Ribosomal DNA for Species Identification in the Plant Pathogen Genus Phytophthora." Plant Microbiology 64(3): 948-954. Rose, J. P., T. J. Kleist, S. D. Lo $\square$ fstrand, B. T. Drew, J. r. Scho $\square$ nenberger and K. J. Sytsma (2018). "Phylogeny, historical biogeography, and diversification of angiosperm order Ericales suggest ancient Neotropical and East Asian connections." Molecular Phylogenetics and Evolution 122: 59-79.

Rosea, J. P., T. J. Kleistb, S. D. Lo $\square$ fstrandc, B. T. Drewd, J. r. Scho $\square$ nenbergere and K. J. Sytsmaa (2018). "Phylogeny, historical biogeography, and diversification of angiosperm order Ericales suggest ancient Neotropical and East Asian connections." Molecular Phylogenetics and Evolution 122: 59-79. Rull, V. (2004). "An evaluation of the Lost World and Vertical Displacement hypotheses in the Chimantá Massif, Venezuelan Guayana." Global Ecology and Biogeography 2004(13): 141-148.

Rull, V. (2005). "Biotic diversification in the Guayana Highlands: a proposal." Journal of Biogeography 32(6): 921-927.

Rull, V. (2009). Pantepui. Encyclopedia of Islands. R. Gillespie and D. Clague, University of California Press.

Rull, V., O. Huber, T. Vegas-Vilarrúbia and C. Señaris (2019). Definition and characterization of the Pantepui biogeographical province. Biodiversity of Pantepui. V. Rull, T. Vegas-Vilarrúbia, O. Huber and C. Señaris, Academic Press: 3-32.

Rull, V., E. Montoya, S. Nogué and O. Huber (2011). "Preliminary palynological analysis of a Holocene peat bog from Apakará-tepui (Chimantá Massif, Venezuelan Guayana)." Collectanea Botanica 30: 79-88. Rull, V., E. Montoya, S. Nogué, E. Safont and T. Vegas-Vilarrúbia (2019). Climatic and ecological history of Pantepui and surrounding areas. Biodiversity of Pantepui. V. Rull, T. Vegas-Vilarrúbia, O. Huber and C. Señaris, Academic Press: 55-67.

Rull, V. and S. Nogué (2007). "Potential Migration Routes and Barriers for Vascular Plants of the Neotropical Guyana Highlands during the Quaternary." Journal of Biogeography 34(8): 1327-1341. Rull, V., S. Nogué, E. Safont and T. Vegas-Vilarrúbia (2019). Pantepui and global warming. Biodiversity of Pantepui. V. Rull, T. Vegas-Vilarrúbia, O. Huber and C. Señaris, Academic Press: 403-417.

Rull, V. and T. Vegas-Vilarrúbia (2019). Pantepui as a dynamic biogeographical concept. Biodiversity of Pantepui. V. Rull, T. Vegas-Vilarrúbia, O. Huber and C. Señaris, Academic Press: 55-67.

Sadowski, E.-M., L. J. Seyfullah, F. Sadowski, A. Fleischmann, H. Behling and A. R. Schmidt (2015). "Carnivorous leaves from Baltic amber." PNAS 112(1): 190-195.

Safont, E., V. Rull, T. Vegas-Vilarrúbia, E. Montoya, O. Huber and B. K. Holst (2016). "Late Holocene vegetation and fire dynamics on the summits of the Guayana Highlands: The Uei-tepui palynological record." Palaeogeography, Palaeoclimatology, Palaeoecology 455: 33-43.

Schluter, D., T. Price, A. Ø. Mooers and D. Ludwig (1997). "Likelihood of Ancestor States in Adaptive Radiation." Evolution 51(6): 1699-1711.

Schönenberger, J., M. v. Balthazar, M. Takahashi, X. Xiao, P. R. Crane and P. S. Herendeen (2012).

"Glandulocalyx upatoiensis, a fossil flower of Ericales (Actinidiaceae/Clethraceae)from the Late

Cretaceous (Santonian) of Georgia, USA." Annals of Botany 109: 921-936.

Schönenberger, J. and E. M. Friis (2001). "Fossil flowers of ericalean affinity from the Late Cretaceous of Southern Sweden." American Journal of Botany 88: 467-480. 
Stamatakis, A. (2014). "RAxML version 8: a tool for phylogenetic analysis and post-analysis of large phylogenies." Bioinformatics 30(9): 1312-1313.

Stephens, J. D., W. L. Rogers, K. Heyduk, J. M. Cruse-Sanders, R. O. Determann, T. C. Glenn and R. L. Malmberg (2015). "Resolving phylogenetic relationships of the recently radiatedcarnivorous plant genus Sarracenia using target enrichment." Molecular Phylogenetics and Evolution 85: 76-87.

Steyermark, J. and G. C. K. Dunsterville (1980). "The lowland floral element of the summit of Cerro Guaiquinima and other cerros of the Guayana Highlands of Venezuela." Journal of Biogeography 7: 285 303.

Steyermark, J. A. (1951). "Sarraceniaceae in Botanical Exploration in Venezuela - I." Fieldiana: Botany 28(1): 239-242.

Steyermark, J. A. and G. C. K. Dunsterville (1980). "The Lowland Floral Element on the Summit of Cerro Guaiquinima and Other Cerros of the Guayana Highland of Venezuela." Journal of Biogeography 7(7): 285-303.

Tank, D. C., J. M. Eastman, M. W. Pennell, P. S. Soltis, D. E. Soltis, C. E. Hinchliff, J. W. Brown, E. B. Sessa and L. J. Harmon (2015). "Nested radiations and the pulse of angiosperm diversification:increased diversification rates often follow whole genomeduplications." New Phytologist 207: 454-467.

White, T. J., T. D. Bruns, S. B. Lee and J. W. Taylor (1990). Amplification and Direct Sequencing of Fungal Ribosomal RNA Genes for Phylogenetics. PCR Protocols: A Guide to Methods and Applications. M. A. Innis, D. H. Gelfand, J. J. Sninsky and T. J. White, Academic Press.

Wistuba, A., T. Carow and P. Harbarth (2002). "Heliamphora chimantensis a New Species of Heliamphora (Sarraceniaceae) from the "Macizo de Chimanta 'in the South of Venezuela." Carnivorous Plant Newsletter 31(3): 78-82.

Wistuba, A., T. Carow, P. Harbarth and J. Nerz (2005). "Heliamphora pulchella, eine neue mit Heliamphora minor (Sarraceniaceae) verwandte Art aus der Chimanta Region in Venezuela." Das Taublatt 53(3): 42-50.

Wistuba, A., P. Harbarth and T. Carow (2001). "Heliamphora folliculata, a New Species of Heliamphora (Sarraceniaceae) from the 'Los Testigos 'Table Mountains in the South of Venezuela." Carnivorous Plant Newsletter 30(4): 120 - 125.

Wong, W. O., D. L. Dilcher, C. C. Labandeira, G. Sun and A. Fleischmann (2015). "Early Cretaceous Archaeamphora is not a carnivorous angiosperm." Frontiers in Plant Science 6.

Wurdack, K. J. and C. C. Davis (2009). "Malpighiales phylogenetics: Gaining Ground on One of the Most Recalcitrant Clades in the Angiosperm Tree of Life." American Journal of Botany 96(8): 15511570.

Zachos, J. C., G. R. Dickens and R. E. Zeebe (2008). "An early Cenozoic perspective on greenhouse warming and carbon-cycle dynamics." Nature 17.

Zinck, J. A. and O. Huber (2011). Peatlands of the Western Guayana Highlands, Venezuela. Berlin, Springer. 
bioRxiv preprint doi: https://doi.org/10.1101/2020.04.29.068395; this version posted April 30, 2020. The copyright holder for this preprint (which

was not certified by peer review) is the author/funder, who has granted bioRxiv a license to display the preprint in perpetuity. It is made available under aCC-BY-NC-ND 4.0 International license.

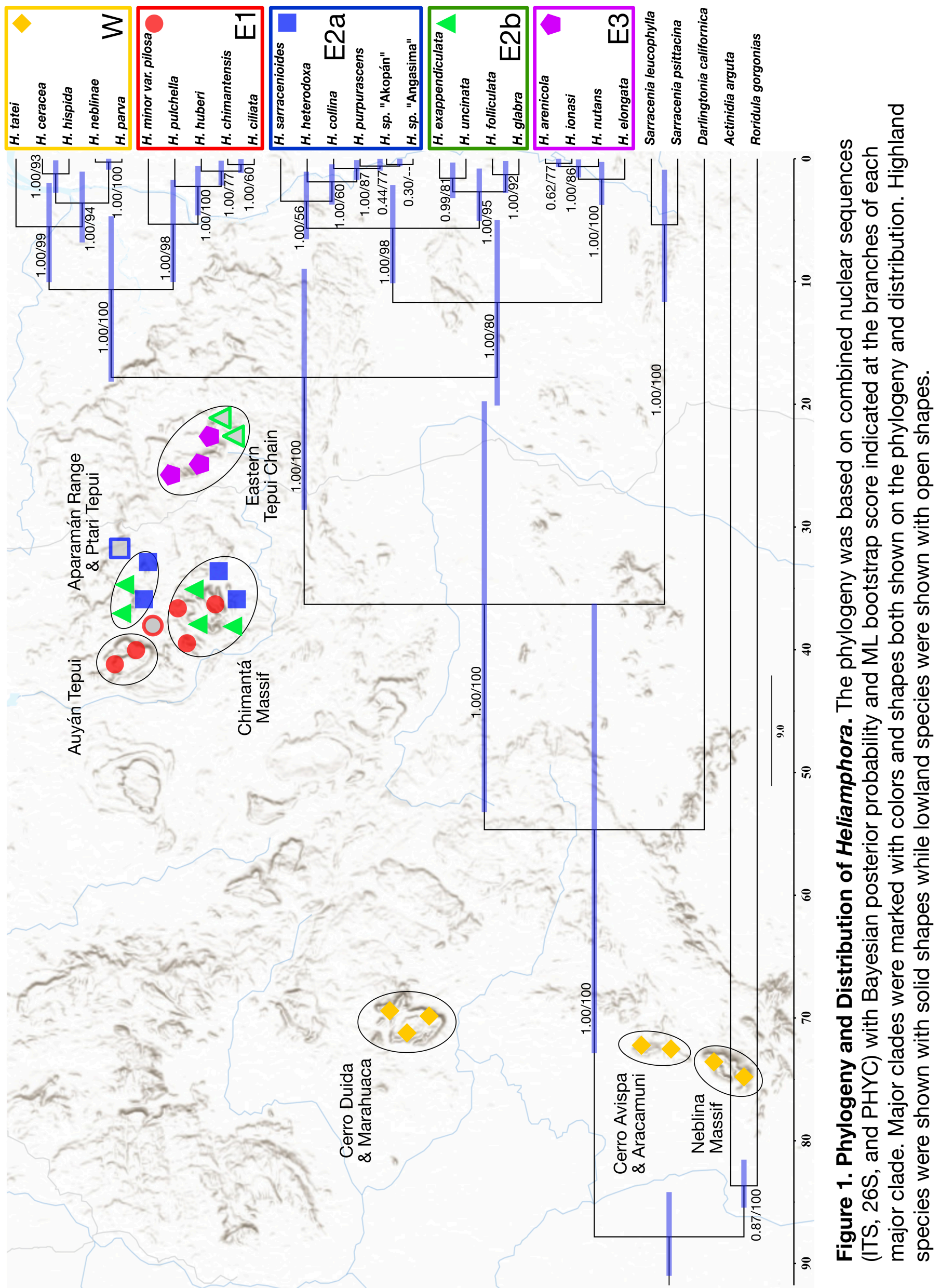




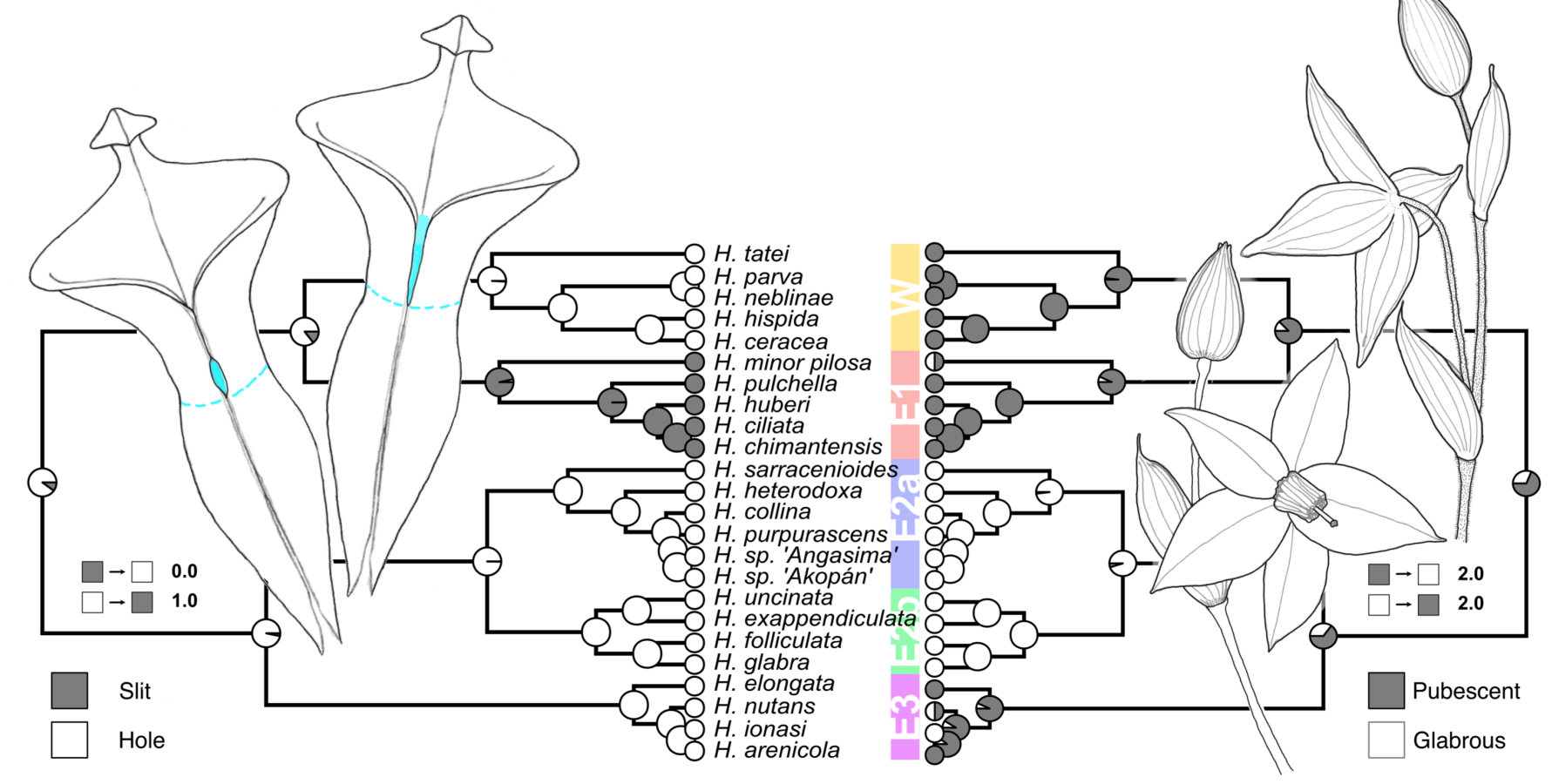

Figure 2. Ancestral state reconstruction of drainage structures (left) and scape pubescence (right) using stochastic character mapping. Median numbers of transitions between states were shown in the legends. In the simplified Heliamphora adult pitchers diagram modified from McPherson, Wistuba et al. (2011), drainage hole, drainage slit were filled with cyan color, and digestive fluid levels were marked with cyan dotted lines. Diagram of Heliamphora inflorescences with pubescent and glabrous scapes were adapted from Fleischmann, Wistuba et al. (2009). Scapes of $H$. nutans and $H$. minor are either pubescent or glabrous, represented with half circles. 


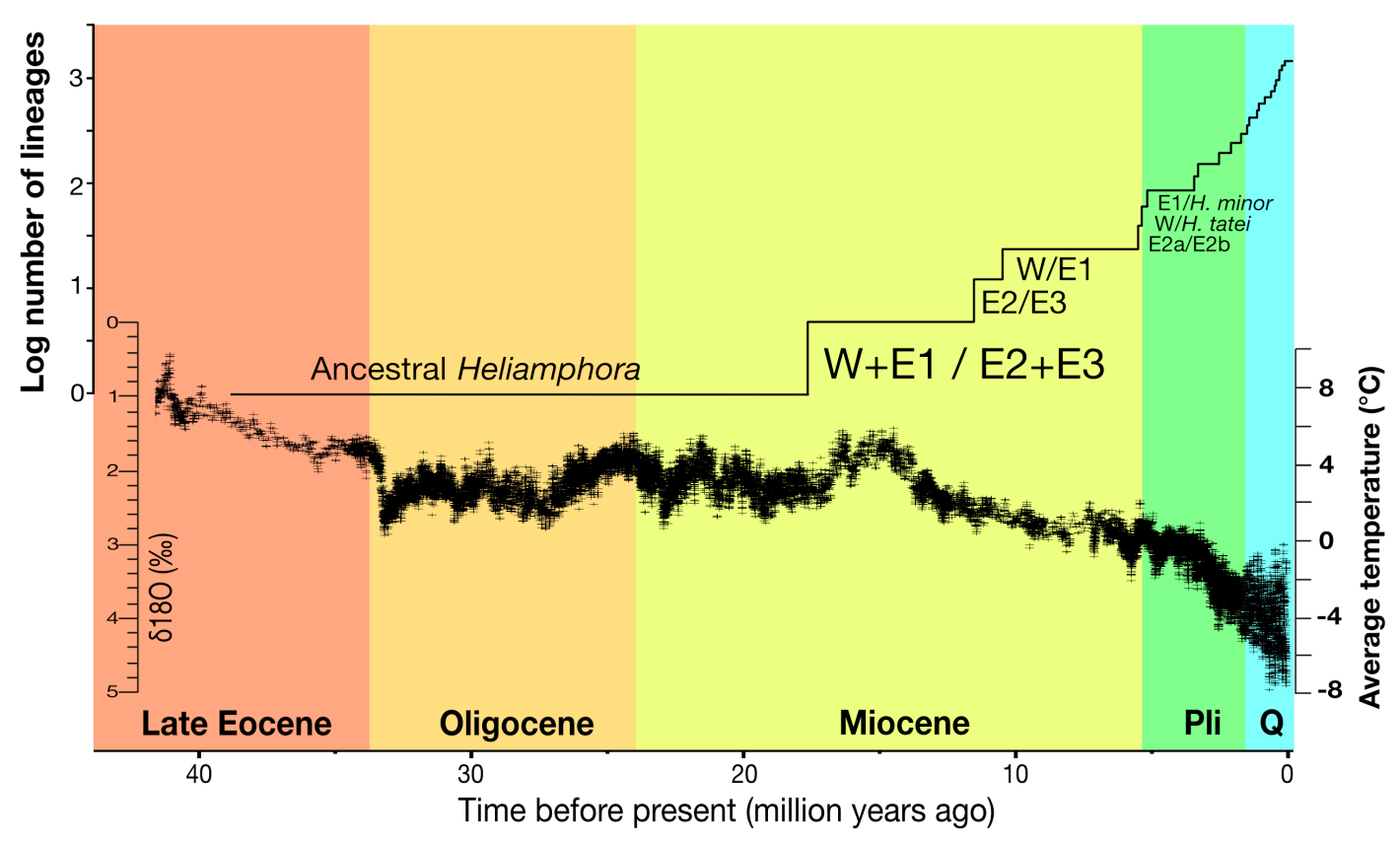

Figure 3. Lineage through time plot on log-scale shows the diversification trend of Heliamphora in relation to the Climate Trend in the Past $45 \mathrm{Ma}$. Major clades in Heliamphora might have emerged by Pliocene (Pli.) when global average temperature drastically decreased and more suitable habitat became available in the Guiana Highland region. During the Pleistocene, Heliamphora diversified rapidly, possibly facilitated by glacial-interglacial oscillations. The climate curve data was obtained from Zachos et al. (2001) and Zachos et al. (2008) based on deep-sea benthic foraminiferal oxygen-isotope curve ( $\delta 180 \%$ ). 